\title{
Gendered forests: exploring gender dimensions in forest governance and REDD+ in Équateur Province, Democratic Republic of Congo (DRC)
}

\author{
Raymond Achu Samndong ${ }^{1}$ and Darley Jose Kjosavik ${ }^{1}$
}

\begin{abstract}
In this study we analyze gender relations legitimatized by socio-political institutions of forest governance in REDD+ pilots in Équateur Province of the Democratic Republic of Congo. Using data from interviews, focus group discussions, and field observations, we show that men and women have different knowledge and use of forests, but these differences are not given due consideration in forest governance. Women's voices are often muted in decision-making arenas and they occupy only a nominal position in both forestry and development initiatives as compared with men. This status quo is extended to the REDD+ pilot projects as well. Women have limited information about REDD+ compared with men. The mechanisms used to establish new village organization for REDD+ exclude women from decision making in the ongoing REDD+ pilot project. We show that women's bargaining power for equal inclusion in decision-making processes and for sharing benefits are constrained by existing social norms regarding local access to land and material resources, existing gender division of labor, local perceptions regarding women's roles and contributions/ responsibilities, as well as men's dominant position in rural settings. For a gender transformative REDD+, we suggest that REDD+ actors should attempt to bring about institutional changes that transform gender relations and thereby increase women's bargaining power.
\end{abstract}

Key Words: decision making; development interventions; Équateur Province, DRC; forest governance; gender role; REDD+

\section{INTRODUCTION}

The differences between men and women in knowledge, access, and use of forests have long been recognized (Meinzen-Dick et al. 1997, Rocheleau and Edmunds 1997, Mwangi et al. 2011, Ingram et al. 2014, Sunderland et al. 2014). This gender disparity is due to the unequal power relations between men and women. These relations of power are constructed and shaped by a host of institutional arrangements that change over space and time (Fraser 1989, Rocheleau et al. 1996, Agarwal 1997, Cornwall 2003). Women's roles and knowledge of forests have been primarily used for subsistence production and nurturing humans and nature. This knowledge is often taken at face value, rather than linking it to socio-cultural settings for better understanding of opportunities and interests (Arora-Jonsson 2013). Although women's knowledge and use of forests are important for forest conservation and management, their voices have long been devalued in forest management decisions (Agarwal 2001, Mai et al. 2012). Mies and Shiva (1993), have exposed how patriarchal science has historically marginalized women as producers of knowledge.

Given these differences in gender role of forest use and management, gender research in forest governance has primarily focused on the inclusion of women in decision-making committees and organizations (Arora-Jonsson 2014, Colfer et al. 2015, Tyagi and Das 2017). Extensive research has identified several characteristics and determinants of women's participation in forest management, but also exclusionary patterns and the effects on forest management outcomes and poverty of women's presence in committees (Agarwal 2001, 2009, Mai et al. 2012, Coleman and Mwangi 2013). These studies point to the fact that the gender composition of forest committees/organizational structures and the sociocultural backgrounds of women significantly affect their attendance at meetings and the probability that they may voice their opinions. Thus, for effective participation it is relevant to consider how power relations operate within decision-making arenas and how they affect the capacity of both women and men to voice their interests.

In a time when new forest conservation initiatives, such as the international mechanism for mitigating climate change by reducing emissions from deforestation and forest degradation, and enhancing carbon storage in forests (REDD+), are being developed and implemented, there is an urgent need to recognize the unequal power relations between women and men in relation to forest resource use and management. It will enable sustainable use, as well as equitable benefits sharing (Peach Brown 2011, Gurung and Setyowati 2012). In this paper, we therefore assess women's and men's knowledge and use of forests, their inclusion in forestry and development interventions, and the ongoing REDD+ pilot activities in REDD+ pilot sites in Équateur Province of the Democratic Republic of Congo (DRC). The main questions include the following: (1) How do women and men differ in knowledge, access, and use of forests in the pilot sites? (2) How do existing forestry and development interventions and the ongoing REDD+ pilot activities include women and men in decision making and benefits sharing? (3) What factors influence women's inclusion in decision making and benefit sharing in these interventions? We address these questions by assessing two REDD+ pilot projects in Équateur Province. Our aim is exploratory, illustrative, and comparative. By doing so, we try to identify and highlight issues related to gender roles, inclusion, and exclusion in these interventions for greater attention to power inequalities between actors in these interventions and the factors that create these inequalities.

\footnotetext{
${ }^{1}$ Department of International Environment and Development Studies (Noragric), Norwegian University of Life Sciences (NMBU)
} 


\section{THEORIZING GENDER: AN ANALYTICAL FRAMEWORK}

Gender is understood as the socially constructed ideas and practices of relations of power between women and men that are sanctioned by cultural, political, and economic institutions (Rocheleau 1995, Agarwal 1997, Pandolfelli et al. 2007, Elmhirst 2011). These ideas and practices are manifested through division of labor and resources; ideologies and representations; and are affected by status, class, and ethnicity, which ascribe to men and women different roles, abilities, preferences, and positions in the social hierarchy (Pandolfelli et al. 2007, Bandiaky 2008). Following this definition, a gender analysis requires an understanding of context specific and intersecting circumstances. That is, gender is mediated by other factors such as wealth, age, status, class and ethnicity, and sexual orientation (McDougall 2001, Colfer et al. 2013). Within forest communities, these factors are significant in assessing gender roles in forests, food security, conservation, and inclusion in decision making institutional structures (Colfer 2013). In this regard, gender is considered a critical variable for analyzing and influencing access, use, and management of forests.

Gender analysis is crucial because women and men have different experiences, needs, interests, strengths, opportunities, limitations, privileges, and biases. These aspects must be reflected in the way communities are approached and explored. In addition, gender has practical and policy-oriented implications because men and women are not homogenous groups. This demands policies that are socially integrated and inclusive and that target them differently in achieving meaningful change (Mai et al. 2012). This is important because many national and international legislations, treaties, and regulations including REDD+ policies have advocated for gender mainstreaming in environment and development interventions (Quesada-Aguilar and Aguilar 2009, Gurung and Setyowati 2012, Nhantumbo and Chiwona-Karltun 2012). Furthermore, gender provides a practical and methodological approach to analyzing opportunities and forms of marginalization by providing a conceptual framework to examine roles, relations, and power patterns. In that sense, gender is a key analytical and explanatory variable in the way we manage forests and resources in general that can help us understand participation and measure forest governance outcomes (Colfer 2013).

In this paper, our analysis of gendered inclusion in forestry intervention and REDD+ is centered on the action resources of men and women, how these determine women's control and relations in forest use and management (Weinberger 2001, Pandolfelli et al. 2007). Action resources are the form of power resources, i.e., wealth, knowledge, information, and social relations, actors (men and women) use in a given context to increase their relationships in forest use and management. These action resources are sanctioned by the institutional arrangements (rules, norms, regulations) that determine how the actions unfold on the ground (Weinberger 2001, Pandolfelli et al. 2007). The institutional arrangements either constrain or constitute the bargaining process (Agarwal 1997).

Taking into consideration the action resources of both men and women and the institutional arrangements that shape these resources, the typology of participation articulated by Agarwal
(2001) is employed to characterize men's and women's involvement in decision-making arenas of these interventions. This typology, compared to other typologies of participation (Pretty 1995), assesses men's and women's inclusiveness in these interventions (Table 1). Participation in interventions ranges from nominal participation (membership in a group or physical presence) to interactive participation in which a member (man or woman) has a voice and influence in the group's decisions. Agarwal (2010) further argues that many interventions focus on the numerical strength of women, rather than their bargaining power to participate better in the very process of decision making.

Table 1. Typology of participation.

\begin{tabular}{ll}
\hline \hline $\begin{array}{l}\text { Form/level of } \\
\text { participation }\end{array}$ & Characteristic features \\
\hline $\begin{array}{l}\text { Nominal } \\
\text { participation }\end{array}$ & Membership in the group
\end{tabular}

Passive participation Being informed of decisions ex post facto; or attending meetings and listening in on decision making, without speaking up

Consultative $\quad$ Being asked for an opinion in specific matters participation without guarantee of influencing decisions

Activity-specific Being asked to (or volunteering to) undertake participation specific tasks

Active participation Expressing opinions, whether or not solicited, or taking initiatives of other sorts

Interactive Having a voice and influence in the group's (empowering) participation decisions

Source: Agarwal (2001)

We further employ Agarwal's (2001) insights to discuss the factors that affect women's participation in these interventions as compared with men's. Following this theoretical insight, women's participation in forestry and development interventions is determined by six factors: rules of entry, social norms, social perceptions, entrenched territorial claims, personal endowments and attributes, and household endowments and attributes. This framework allows us to focus on the dynamics of power and to analyze how barriers to women's participation in these interventions are constructed by the underlying power relations between women and men (Rocheleau et al. 1996, Agarwal 2001).

\section{STUDY AREA AND RESEARCH METHODS}

As indicated, the data for this paper was collected from two REDD+ pilot projects located in the Équateur Province of the DRC (Fig. 1). Équateur Province was divided into five new provinces in July 2015, following the national decentralization reform, but our analysis is based on the province's political and governance structure before the division. The first pilot site is located in the Buya 1 village of Bikoro territory southwest of the old Équateur Province, which is now the new Équateur Province. Its dominant vegetation is equatorial swamp rainforest, inundated year round, making road construction and maintenance difficult (Yamba 2009). The second pilot site is located in Bokumu-Mokola 
Fig. 1. Map of the two pilot sites in Equateur province: (a) Bikoro territory, Buya 1 project village, (b) Gemena territory, Bokumu-Mokola project village. Source: M. Chapman, Wood Hole Research Center, 2016.
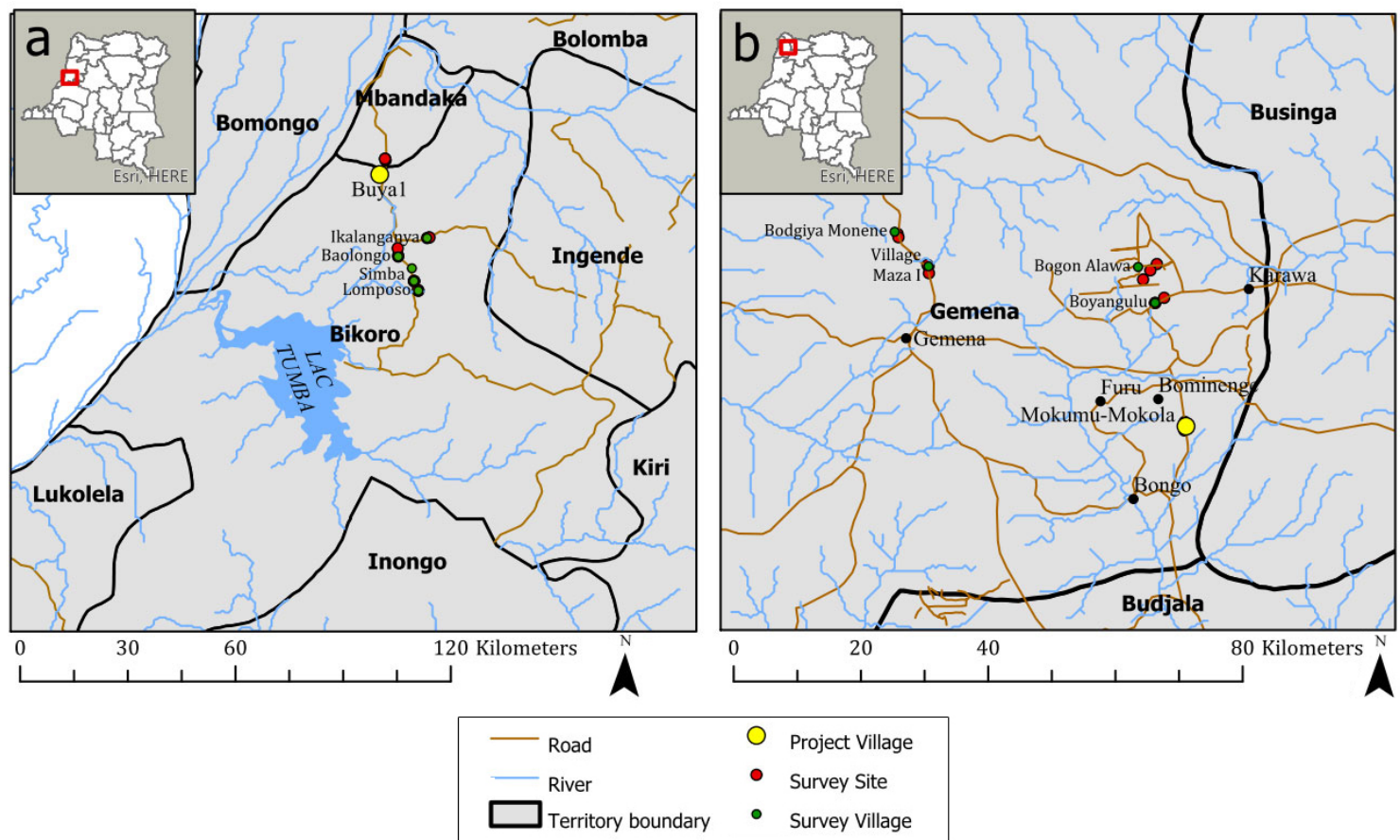

village of Gemena territory, northwest of the old Équateur Province, which is now the Sud-Ubangi Province. Here the dominant vegetation is dense, humid, equatorial lowland rainforest that transits into evergreen savannah woodland and grasses in the north. The people of both pilot sites rely heavily on the forest for their livelihoods, practicing slash and burn shifting cultivation, extracting nontimber forest products, fishing, hunting, and producing charcoal.

Woods Hole Research Center (WHRC) manages the REDD+ pilot project in partnership with the Ministry of Environment and Sustainable Development with support from the Congo Basin Forest Fund. The pilot project was initiated in 2011 with the aims to (1) increase the capacity of regional actors in the development of REDD+ strategies and preparation for the management of carbon funds, and (2) design and implement community-based REDD+ pilot projects with potential for continued carbon financing.

Ethnically, the pilot sites consist of two main ethnic groups: the Bantu and the Batwa. ${ }^{[1]}$ The Batwa are found in the Bikoro pilot site and make up about $20 \%$ of the population in the territory. They are considered migrants by their Bantu neighbors in the study area, and hence have limited rights to land and forest. The Bantu group is divided into different tribal groups (the Mongo, Ntomba, and Ekonda including other migrant groups, and Ngbaka in Gemena).

The two pilot sites are different in terms of their landscapes, economic activities, accessibility, and external interventions. The Bikoro pilot site has experienced several interventions related to agricultural development, forest governance, and conservation from different international and national nongovernmental organizations (NGOs). The Gemena pilot site, for political reasons, ${ }^{[2]}$ has experienced very little of these interventions. In Bikoro we focused on the food security project implemented by Bureau Diocésaine de Développement (BDD), the World Food Program (WFP), the Food and Agricultural Organization (FAO), Oxfam, and the ongoing REDD+ pilot project. In Gemena, we focused on the agricultural training project implemented by the Humana People to People Congo (HPP-Congo) and the ongoing REDD+ pilot project.

The field research was conducted in May-July 2013, July-August 2014, and July-August 2015. Information was obtained through interviews, focus group discussions, and field observation. We interviewed 72 people from 6 categories of actors (Table 2) using snowball and purposive sampling. Our intention was to gather information on men's and women's knowledge, access, and use of forests, their inclusion in decision-making arenas, and the factors that constrain women-s inclusion.

We organized nine focus group discussions (FGDs) in total in both pilot sites with 10 participants in each group to capture the local people's insights of these issues. Five FGDs were organized in Buya 1 village with men, women, customary landowners (ayant droit), migrants, and Batwa groups; and four FDGs were organized in Bokumu Mokola with men, women, customary landowners (ayant droit) and the migrants. In addition, field observations were made concerning the availability and quality of infrastructure such as roads, schools, health care and community activities, rights to land, information and material 
Table 2. Category of actors interviewed in both pilots.

\begin{tabular}{|c|c|c|c|c|c|}
\hline \multirow[t]{2}{*}{ Category } & \multicolumn{2}{|c|}{ Bikoro pilot } & \multicolumn{2}{|c|}{ Gemena pilot } & \multirow[t]{2}{*}{ Total } \\
\hline & Male & Female & Male & Female & \\
\hline Customary authorities & 3 & 2 & 4 & 2 & 11 \\
\hline Local administrative authorities & 3 & 0 & 2 & 0 & 5 \\
\hline NGO staff & 5 & 2 & 4 & 1 & 12 \\
\hline Executive members of village associations & 8 & 6 & 4 & 6 & 24 \\
\hline REDD+ pilot staff & 4 & 0 & 0 & 0 & 4 \\
\hline Representatives of the REDD+ village organizations & 8 & 0 & 7 & 1 & 16 \\
\hline Total & & & & & 72 \\
\hline
\end{tabular}

resources, village meeting place, and the local peoples' mode of engagement in meetings.

\section{RESULTS}

\section{Cannot see the forest for the trees? Exploring differential} knowledge, access, and use of forests

Information gathered from the interviews and focus group discussions revealed that both men and women in the project sites have different knowledge of the forest. The women in both pilot sites view their forest as a place with fertile soil for farming and with many nontimber forest products (NTFPs) for consumption and cash income, and as a place to collect firewood for the household. Women attach more importance to the collection of NTFPs that make a significant contribution to household consumption and cash income. The view of the forest from Batwa women in Buya 1 village was not dissimilar to the Bantu women. They mentioned in the focus group that the forest is a place to collect NTFPs and for cultivation. For the men, the forest is a place with big trees to harvest timber, a place with sticks/poles and material for construction, a place with trees to produce charcoal, a place with many wild animals for bush meat, and a place full of different NTFPs and medicinal plants for subsistence use and cash income. The men in Bikoro pilot site heavily referred to the forest as a place for charcoal production, whereas the men in the Gemena pilot site heavily cited the forest as a place of many food trees ${ }^{[3]}$ and medicinal plants. This difference in views is because charcoal has become an important economic activity in Bikoro, with increased demands from the big towns and being easily accessible, compared to Gemena. The men in Gemena attached high value to the caterpillar food tree, because of its high economic value in the area. In both pilot sites, the men of the customary landowners' focus group mentioned that the forest is a place inhabited by the spirits of ancestors, with strong cultural importance. The Batwa men had a quite different view of the forest compared to the Bantu men. In their focus group, they indicated that the forest is a place to hunt wild animals, fish, harvest forest products and medicinal plants.

The main reason for this difference in knowledge of the forest between the men and women was that the men are mobile compared to women, hence, they know more about the forest, its boundaries, and the location of different forest resources compared to the women. The women's role is to nourish and cater for their households, while the men perform the outdoors activities. This women's role of caretaking has limited their knowledge about the harvesting and processing of products that helps to improve household food security and, in fewer cases, their cash income, while the men's role is concentrated on high-value forest resources for market exchange. Women's knowledge of forests, although limited to NTFPs, is important for the household to cope with shocks such as drought, food shortages, and low income.

The information gathered from the interviews and focus group discussions revealed that the difference in knowledge of the forest between the men and women is related to how they access and use the forests. The women in both pilot sites have limited access to and control over the forest. Their rights to forests are meditated by menfolk (father, husband, or son) and enshrined in the customary tenure of forestland. In terms of forest uses, amount of extraction for forest products and the conversion of forestland into agricultural land is the principal livelihood activity in both pilot sites. Information gathered from the interviews and focus groups indicated that both men and women differ in the ways they engage in farming, their crops, and tasks. The opening up of the forest for the establishment of the farmland requires sheer physical strength and is principally the men's task. The men do very little work once the clearing is done, and the rest of the work in the field (planting, weeding, harvesting) is women's responsibility. Gender differences were observed in the types of crops cultivated in the farm fields. Men focus on the cultivation of food crops with high market value such as plantains and palm trees, while women's main concern is subsistence food crops. Information from the interviews and focus group discussions also revealed that men are now increasingly involved in the production of groundnut and maize because of their high market value. In addition, the men in Gemena pilot site are now increasingly involved in the harvesting of caterpillars, especially the young adult men, because of the relative scarcity and high demand in the markets. The women in Gemena pilot sites reported in their focus group that the young men now trek long distances into the forest for days to harvest caterpillars, while their domestic responsibilities do not permit them to do so.

Forestry and development interventions: two tales on the nature and process of participation

Muted voices in local forest management institutions

The customary system of forest management is practiced in both pilot sites. According to this customary system, each village in the pilot sites has a traditional council headed by a village customary chief with the notables (the head of the main clans in the village) and some elderly members of the village as representatives. This council makes decisions about village land allocations and 
enforces property rights over the village forests. In Bikoro and Gemena pilot sites, the village traditional councils are made up of seven and eight members, respectively, and in each case there are only two women. The customary landowners nominate these female members based on age and virtue. Although women are represented in the village traditional council, they are not included in decisions related to land allocation and forest management. When there is a conflict related to land allocation and management in the village, only the men with customary claim to land (ayant droit), the notables, customary chiefs, and tribal chiefs are invited to mediate. Hence, the decision made would not reflect women's views. A woman who is a member of the village traditional council in Mokumu-Mokola in an interview noted the following: "we do not have power to influence decisions in the council. Our presence is to give advice on issues related to women's access and use of forests when there is a conflict" (Interviewed August 2015). The local norms and customs allow women to inherit farmland from their father. In practice, however, early and forced marriage makes this difficult. Moreover, women are expected to gain access to land via their husbands. Single women's rights to inherit from their father are often contested by their male siblings. This was reported in the women's focus groups in both pilot sites. Moreover, women have very limited access to and control over forest resources. Women do not control access to forestland but maintain their access through relationships of patronage, marital status, or family support from husbands, fathers, uncles, or sons. Women are involved in forest related decisions only at the household level such as where and when to cultivate, what crops to plant in the different fields, organization of household and farm activities.

Apart from decisions related to land allocation and management, the customary chief is the main intermediary for the negotiations of the social agreement and logging compensation with the logging companies in the Bikoro pilot villages. This is based on the 2002 Forest Code (article 44 and 89), the 2006 Constitution (article 34 and 56), and Arrêté 023 issued by the Ministry of Environment on 7th June 2010 (GDRC 2002). Inclusion and benefits from these negotiations are based on ethnicity and customary rights to forestland. Only the customary landowners, who are mostly men, are involved in the negotiation and they are paid the logging compensation. Women are not included in the negotiations because they do not control access to forestland. Married women may benefit from logging compensation via their husbands. There is no logging concession in Gemena pilot village, but artisanal operators negotiate their access and rights to log the forest with the customary chiefs and notables. Women are not involved in this process.

\section{Underrepresentation of women: the food security project of Buyal village in Bikoro pilot site}

Village level associations known as Organization Paysanne de Development (Peasants' Development Organizations), referred to as OPDs, were recognized to implement the project activities in the village. These village associations have legal status and operate as a platform through which intervening agencies train villagers, supply materials and inputs to improve agricultural production, and engage in other development activities (Samndong 2016). Among the 21 OPDs that exist in Buya 1 village, only four were chosen for the food security project. Among these was one women's association (Table 3). Membership of these OPDs is open to everyone living in the village and is based on a fee equivalent to US\$1-2 and a monthly contribution equivalent to US\$0.5-1. Very few women are members of these OPDs (Table 3 ) and very few women participate in the meetings and activities of the associations.

Table 3. Gendered membership in village associations recognized in the food security project of Buya 1 village.

\begin{tabular}{lccc}
\hline \hline Village associations & $\begin{array}{c}\text { Number } \\
\text { of Men }\end{array}$ & $\begin{array}{c}\text { Number } \\
\text { of } \\
\text { Women }\end{array}$ & Total \\
\hline Regroupement de Cultivateurs de Buya 1 & 18 & 7 & 25 \\
Action pour le Développement & 18 & 7 & 25 \\
$\begin{array}{l}\text { Communautaire } \\
\text { Centre Agropastorale de Buya 1 }\end{array}$ & 10 & 5 & 15 \\
$\begin{array}{l}\text { Association des Femmes Paysannes de } \\
\text { Buya 1 }\end{array}$ & 0 & 25 & 25 \\
\hline
\end{tabular}

In the Focus groups, women complained that their domestic responsibilities and farm activities hinder their participation in the meetings and activities of the associations. This is because the time set for these meetings often conflicts with their activities and most men are unwilling to cover for their wives in household chores given the prevailing gendered social norms. Women pointed out that meetings mostly take place during the day when most women are out in their farm fields or forests. Some meeting dates and locations are often announced in the village, but the information does not reach all village members, especially women. This gives men the advantage in having first contact with the intervening agencies, access to information and networks. Some women reported that their husbands do not allow them to join the associations. "Our husbands think the associations make us disobey them and challenge their authority," said a young woman in Buya 1 village, a statement that was confirmed by many. The Batwa women specifically mentioned that they could not afford the membership fees and other mandatory contributions. The discussions further revealed that the active members of the women's associations are women who have experienced some forms of outside exposure, training, and education.

The executive members of these OPDs are elected from the general members with four years renewable term of office. To be an executive member of the OPD, one is required to be able to read and write in French, speak well in public, have some physical assets (valuable properties such as house, land, livestock), educated above secondary school level, command respect in the village, and able to protect the interest of the village. Very few women $(30.6 \%)$ have completed primary education in both pilot sites (Samndong 2014). This limits their ability to become executive members of the OPDs. In RCB, ADC, and CAPB1 there is only one woman in each association as executive member. Women hold only the office of the treasurer and they have been replaced twice in the RCB and ADC. The executive offices held by men have never been replaced since the creation of these OPDs. During an interview, the president of RCB in Buya 1 noted that participation in meetings was very important for one's voice to be heard in decision-making matters. Other members confirmed this statement during the focus group discussion. An Oxfam interviewee in contrast reported that women's inclusion in the 
executive committee of these OPDs is often imposed by the intervening agencies, though culturally it is not accepted that women be engaged in public meetings. Even when included, their voices are often ignored. The executive committees of the OPDs are the decision-making bodies. The committee members received training, information, resources to organize meetings and activities in the village, and farm tools to be distributed to members. Women are underrepresented in the executive committee hence are excluded from these training and information.

Although women are underrepresented in these committees and excluded in the training activities, they still acknowledge that their knowledge of forest is relevant for the food security project. This was clearly articulated by the president of the women's association (AFPAB) who noted that the following:

\section{[W] know the food crops to grow in our forest. We know where to grow what food crops and the soils that produce much, which insect or diseases affect our crops, but very few women participate in the different workshops organized by $F A O, W F P$, Oxfam, and BDD in our village and very few women received support. The men dominate these workshops, but they don't use the forest the way we use it and do not share this information the way it was given.}

Women are invited to these project meetings just to sit, for nominal participation (physical presence), because their voices are not included in the final decisions. Many women do not participate in the training workshops and hence lack information. No woman participated in the rice cultivation demonstration activity organized by WFP/FOA in Buya 1 and only men own rice fields because they are cultivated in the swamp forest where heavy physical work is required and perceived as a man's job.

Several men mentioned that the local norms prohibit women to participate in public decision making in the presence of men. The men of the focus groups in Buya 1 village noted that the following:

[I]n our culture, once a woman's bride price is paid and marriage rites have been performed by her husband, that woman becomes the responsibility of her husband and subordinate to his decisions or instructions. She may make suggestions or contribute by supporting a viewpoint, but cannot make decisions.

Some women, especially married women, mentioned that they need the approval of their husbands to become members of the OPDs and to attend the meetings. Most men often refuse to allow their wives to forego domestic chores for the sake of project activities and meetings. However, some men in the focus groups indicated that they attempt to support their wives in domestic duties, but their fellow men and even some women often stigmatize them. This hinders their effort in supporting their wives.

Our field observations revealed that women in the project sites, especially married women, were submissive in their behavior. The married women noted that it is disrespectful and culturally unacceptable for a married woman to speak boldly in front of men in public. In addition, the women in the focus group in Bukumu - Mokola noted: "Although our culture demands of us to be loyal to our husbands, our Christian doctrine teaches us to be submissive, respectful, and obedient to our husbands."
However, the women of the focus group in Buya 1 village confirmed that, some married and single women in the village are courageous to speak in public even during village assembly meetings in the presence of men. These women have some forms of outside exposure, training, and education. Some men noted that despite the cultural norms, some single women and widows in Buya 1 often speak boldly and even insult men openly. Some of these women, have been stigmatized as "iron women or men in women's form" in the village.

Women benefit very little from the food security project compared to men because of their limited participation given that they are nominal participants. For example, the women received little information and training from the project. The farm tools that are provided by the project are distributed to only the members who have paid their membership fees and contributions and are active in the meetings. The president of RCB, in an interview noted: "if my association receives materials from our partners, we distribute these materials to all registered members of the association, but if we have field activity only those who participate in the field activity benefit" (interviewed in July 2015). Several women noted that they participate in these meetings just to benefit from the per diems that are distributed to participants. Because women are good in mobilizing labor, especially women from the women's association Mama Lamuka, they are often hired in the activities.

Although women's participation in the food security project in Bikoro seemed to be passive, they were still able to use different mechanisms to exercise their agency and resist male authority (Table 4). Information from the interviews and focus group discussions revealed that both men and women used different accountability mechanisms to hold the OPD executives accountable. Apart from elections, which both men and women confirmed to use to remove or endorse the executive members and which is inscribed in the OPD regulations, the other mechanisms were not decisive but created impact on the social status and prestige of these members.

Table 4. Gendered forms of accountability mechanisms used in Buya 1 village.

\begin{tabular}{lcc}
\hline \hline Available accountability mechanisms & Used by men & $\begin{array}{c}\text { Used by } \\
\text { women }\end{array}$ \\
\hline Elections & +++++ & +++++ \\
Public confrontation & ++++ & + \\
Report to higher authority & ++++ & + \\
Threatening violence & +++ & + \\
Boycott village meetings and activities & ++++ & +++ \\
Sabotage activities & ++++ & ++ \\
Shame leaders & +++ & ++ \\
Make up stories & ++ & ++++ \\
Spread rumors & + & ++++ \\
\hline
\end{tabular}

The codes represent the use and strength: + not used, ++ low use, +++ constant use, ++++ high use, +++++ heavy use

In order to implement the agricultural training project, HPPCongo created three-village associations known as Molende 1, Molende 2, and Laka in September 2014. Although membership in these associations is open to everybody in the village, only 25 individuals have registered in each of the associations. In Molende 1, Molende 2, and Laka; there are 15, 13, and 15 women, 
respectively. There is no membership fee, however, each registered member is required to contribute US $\$ 2$ for the legalization of the association documents. Each of these associations has five members in their executive committee including a woman as treasurer. The village traditional council appoints the president and the president then appoints the committee members through consultation with the members. The general assembly of the associations makes the decisions while the committee executes the decisions and reports to the assembly. More than $50 \%$ of the members of these associations are women. Information gathered from the interviews and focus group discussions revealed that men did not have much interest in joining these associations because about $80 \%$ of the farming activities in the village are performed by women. It was further revealed that during the consultation meetings with the local people, HPP-Congo deliberately encouraged women to join these associations given that they were the ones that do most of the farming activities.

The agricultural training program in Bokumu Mokola village is still ongoing. Information gathered from the interviews and focus group discussions indicated that although women are underrepresented in the executive committee of these associations, they are actively involved and engaged in the project meetings and activities. Their underrepresentation in the executive committee was because they needed members who are able to read, write, and communicate freely with the staff of HPPCongo. The women, however, pointed out that the general assembly made all the decisions of the associations. The executive committee reports to the general assembly and all the members are informed about the projects and the activities. The women in the focus groups noted that because decisions are made in the general assembly, they are involved through either voting or negotiation. They also indicated that they are motivated about the project because their interests are considered. Several women mentioned that since the project is related to their activities in the forest, they are encouraged by their husbands to participate in the training and the meetings. However, some women complained that their household chores often constrained them to participate in the meetings and training. A staff member of HPP-Congo interviewed reported that they always try to organize meetings and training at a time that is convenient for women. This convenient time is often difficult to find because of other constraints like the weather, the bad roads, and the meeting venue of the village. HPP-Congo has established three demonstration plots in the village, where the members are trained on different techniques for cultivating different food crops to produce high yields. All members of the associations participated in the different training activities. Each member receives the training, a machete, two hoes, and high yield seedlings. The next phase of the project is for the members to implement the training they have received and test the new seedlings on their farmlands.

\section{REDD+ pilot project: a man's world}

Once bitten twice shy: women's reservations on REDD+

Across both pilot sites, the awareness of REDD+ was higher among men than women although all confirmed that they have heard about REDD+. Some members of the men's focus group in Buya 1 noted that the REDD+ project would provide them with local alternative livelihoods such as agroforestry and micro credit scheme. The men in Bokumu-Mokola also reported that $\mathrm{REDD}+$ is a forest conservation project that will provide the village with innovative agricultural practices, agroforestry, social infrastructures to protect the forest. Some men in the focus group emphasized that REDD+ was a payment mechanism to protect the forest, but did not understand how this payment would be done.

Not all women in the women's focus groups in both pilot sites were aware of REDD+. In the women's focus group of BokumuMokola village, the women who claimed to know the project noted that the project was named "Zamba Malamu," a new project that will reduce poverty in the village, protect the forest by helping them practice their agriculture in fallow land, improve soil fertility in degraded land, and provide them with farm inputs. Some women in Buya 1 village also shared these views but also added that the REDD+ project would provide the village with portable drinking water, schools, and micro credit scheme.

Gender knowledge of REDD+ was based on information received during the introduction of REDD+ in both pilot sites, the free, prior and informed consent (FPIC) process. During the introduction process, a village assembly meeting and workshop were held to inform and create local awareness regarding the project goals, expectations, and outcomes. The women who participated in the meeting and workshop were positive about the information they received about their village being selected for the REDD+ project for development. These women, however, believe that the REDD+ project is meant to benefit only men because their attendance was considered more important than the women's and because the men always receive the information. Information gathered from the focus groups, revealed that many women did not attend the village assembly meetings and workshop in both pilot sites. Men have more leisure time and are more involved in village affairs than women. The men were the first to receive information about this meeting because they are often home during the day while the women are either in their farms or behind the house working. The nature of the gender division of labor favors men and gives them access to vital project information, constraining women's access to such information. During the women's focus group discussion in Buya 1, a woman was supported by other women when she stated the following:

Our culture makes life easy for the men because they do
not prepare food or care for the children. The men work
hard in their fields but when they come back home they
relax and socialize with their friends. They are concerned
with only what their wife gives them to eat, they are not
concerned about how she has been working all day to
make sure he would get food to eat (focus group
discussion, July 2015).

Some women in the focus group in Buya 1 village noted that many women are skeptical about REDD+ because of their experience with past development projects. These women indicated that many past interventions in the village had excluded them from the benefits. Women in both the study villages were afraid that REDD+ might reduce their access to forest, which they depend on for their livelihoods, whereas some men saw REDD+ as a new opportunity for them to generate income from alternative livelihood activities.

However, the men who received information about the village meeting did not circulate it to all the village members. A few men told their wives about the meeting as revealed in the focus group 
discussions. The customary chief of Buya1 village noted that the individual who was assigned to announce the meeting to all village members gave the information to selected households, mainly clan members and friends. Some men who had access to the radio mentioned at the village assembly meetings in Gemena pilot site that they had heard about REDD+ as a new strategy the government of the DRC had engaged to protect the forest.

Women's exclusion from REDD+ village organization: a question of household heads?

WHRC together with its partners have established a new village organization for REDD+ in both the pilot sites. Before the establishment of these organizations, meetings were organized to inform the local people and to set up the process. Across both pilot sites very few women participated in the process of establishing these village organizations compared to men. The women noted that the time for these meetings conflicted with their household chores and farm activities. The men were free to participate in these meetings because the household division of labor does not constrain them. Some women in the Buya 1 village indicated that the meeting venue was not conducive for them. The meetings took place at the meeting venue of the customary chief's residence and there were no seats for the women because the men had occupied them all. Some women had to bring their own seats while others sat on the floor. The women who participated in these meetings indicated that they were motivated to participate because of the per diems they received after these meetings.

The organizations were established to ensure that all the households in the village are included in the project activities and benefit streams. The mechanism used to establish these village organizations excluded women from participating in decision making regarding REDD+ in the village. In both pilot sites, only the household heads were selected by the project organizer to form groups that were used to elect the executive members of the organization. More than $80 \%$ of the household heads in both pilot sites were men. Hence very few women, mostly single women and widows, were selected to form these groups.

In Buya 1370 household heads were listed of which only 52 were women. In total, 37 groups were created using the list of household heads in the village. Each of these groups then selected two members to represent them in the REDD+ village committee. This committee of 74 members then elected an executive committee of four members (President, vice president, and two technical advisers) known as the REDD+ Focal Point of the village. The president elected was the village customary chief and the vice president was a woman. It was a perquisite for WHRC that a woman should be a member of the executive committee.

In Bokumu-Mokola, 360 household heads were listed of which only 21 were women. In total, 36 groups were created from the list of household heads. Each of these groups then selected two members to represent them in the REDD+ village committee. This committee of 72 members then elected the executive committee of four members (President, vice president, and two technical advisers) known as the REDD+ Focal Point of the village. The president elected was a customary landowner and no woman was elected to the executive committee. The criteria used to elect members of the executive committee excluded women to be members. Although the village organization has been established, it still lack the rules and bylaws to function in both pilot sites, and will require legal recognition.

Early REDD+ demonstration activities: Are women included? WHRC and the local partners have been implementing some early REDD+ demonstration activities in Buya 1 in the Bikoro pilot village. These activities include a village water project, construction of a school building, samples of improved household cooking stands, samples of artisanal ovens to dry and process cassava, agroforestry demonstration plots for fruit tree nurseries, soil enrichment plant, and demonstration plots for rice cultivation in swamp forest. No demonstration activity has been introduced in Mokumu-Mokola village in Gemena pilot village. The water project was the first REDD+ project activity implemented in Buya 1 in June 2014. The WHRC's partner BDD constructed three wells at different locations in the village. Based on information from the interviews and focus group discussions, the local people apparently had negative views on the water project. The wells constructed did not provide water to the village during the first dry season in 2014. The women complained that they are now forced to trek long distances to fetch water which increased their workload. They indicated that although it is their role in the household to collect water, they were not included or represented in the decisions to construct the wells, their locations, and the planning of the project. Very few women, compared to men, participated in the well construction as laborers. These women complained that they were forced to use their own tools without compensation and they were also not paid. One woman confirmed that she was injured during the construction work and was not treated by BDD and the village authority.

Women did not participate in the agroforestry demonstration plots, fabrication of bricks to construct the school, and the rice cultivation plot. The men's focus group mentioned that these activities were mainly for the men because they require physical strength. In addition, though women have good knowledge about farming and use of forest to improve food security, only the customary landowners (only men) were involved in the agroforestry demonstration activities. Despite strong concern expressed by the staff of WHRC to include women in the project activities and to ensure that women are strongly represented in all project activities, their project partners have included only men in the ongoing activities on the pretext that these activities are for men. Women's associations are not recognized as partners in the project. The staff of WHRC mentioned that various activities have been planned for women to be implemented, but the project implementation is behind schedule because of delays in disbursement of funds from the fund manager and national government.

\section{DISCUSSION}

In this paper, we investigated gender roles and knowledge of forests, inclusion in forestry, development interventions, and the barriers of women's inclusion in decision-making structures and processes. The findings show that women and men's day-to-day economic roles, knowledge, and responsibilities differ substantially in the REDD+ pilot sites. These differences are created by existing socio-cultural norms in the study area that constrain women's ability to participate in forest governance processes. Two key findings from the results are discussed below. 


\section{Gender roles and inclusion in decision-making structures and processes}

The findings reveal that gender roles and responsibilities shaped women and men's knowledge of forests. Compared to men, women's knowledge of forests is more directly geared to household food consumption and health, which is particularly important for food security. This knowledge is important for the household to cope with shocks such as drought, food shortages, and low income. The men's knowledge of forest is linked to high valued resources for market exchange. Given that women's knowledge is linked to subsistence and not economic exchange, this knowledge is often undervalued in forest management (Peach Brown 2011, Guarascio et al. 2013). For example, women in the study sites are ascribed specific roles such as childcare and household care (cooking, cleaning, fetching wood and water, etc.) based on socio-cultural norms, and not necessarily because of ability, based on comparative advantage. These domestic chores constrain women from engaging in more income generation activities such as harvesting of caterpillars at long distances or being involved in logging activities and charcoal production.

In addition to the socio-cultural ascribed roles, the physical strength and product preference influences the ways men and women access and use the forests (Colfer 2013). Opening up the forest for agriculture was considered a man's task in the study area because of their physical advantage whereas the women are more engaged in planting, weeding, and harvesting. The forest products harvested and crops cultivated were different between men and women. The men are engaged in high valued food/cash crops and NTFPs for market exchange whereas the women are engaged in food crops and NTFPs for subsistence and food security. These findings resonate with findings from Cameroon where Bantu women's role in agriculture was vital for food security (Brown and Lapuyade 2001, Veuthey and Gerber 2010). These findings reveal that gendered roles and responsibilities of forest use and management are rather nuanced and require policy makers to consider these nuances in gender roles while designing localized and context-specific policies.

We characterized the levels of inclusiveness in decision-making structures and processes using the Agarwal (2001), typology of participation. The findings reveal that compared to men, women exhibited nominal participation in the different interventions. Women are not involved in decision making regarding forestland allocation and management in both pilot sites. The elderly and virtuous women often represent women in the village traditional council but their voice over decision making is limited. This finding highlights the fact that women's representation in the village traditional council does not necessarily lead to the highest level of participation as also documented in other studies (Tiani et al. 2016, Tyagi and Das 2017).

Women also exhibited nominal participation-membership of the different OPD recognized in the food security project in Buya 1 village. Some women, especially the Batwa women, could not even attain nominal participation because they could not afford membership fees, hence were excluded from the food security project. Even though some women are members of these OPDs, they attend project meetings just as listeners because their voices are ignored in decision-making matters. Moreover, many are motivated to attend these meetings just to benefit from the per diems. In addition, women are underrepresented in the decisionmaking bodies (executive committees) of these associations. Their inclusion in these executive committees is externally imposed and their voices are excluded in decision-making matters. This clearly demonstrates that women's inclusion in the food security project is considered as window dressing (Mohanty 2004, Awung and Marchant 2017).

However, a few women in these OPDs were able to make their voices heard in decision-making processes. They are women who have experienced some forms of outside exposure, training, and education. Although, the majority of the women exhibited nominal participation in the food security project, they were able to use other forms of accountability mechanisms, "weapons of the weak," to influence the male dominated structures (see Scott 1985). These forms of accountability mechanisms are quite common and frequent in many marginalized groups in the Congo Basin (Oyono 2004).

By contrast, in Mokumu-Bokola, women participated more in the agricultural training project and exhibited more active participation. Women were highly represented as members in the different associations established by the project. This finding supports the ideal that women's high representation (critical mass) in mixed groups have a greater chance of self-sustained collective action outcomes (Arora-Jonsson 2014, Tyagi and Das 2017). Nevertheless, women's high representation in these groups was because men were not interested in the project. In situations where men are interested in the project, women are often represented through separate women's groups like in the case of the food security project in Buya 1 village. This finding illustrates the fact that genuine gender transformational change in forestry and development interventions can only occur if the socio-cultural basis of exclusion (men's entrenched claims) is weakened (AroraJonsson 2014).

Women's high representation was also due to the nature of the decision-making body of these associations. In Mukumu-Bokola, women were underrepresented in the executive committees of these associations but the decision-making body was the general assembly allowing them to make their voices heard in decisionmaking matters. This was different in Buya 1 village where the executive committees were the decision-making bodies and women were underrepresented in these committees. This finding reveals that for women to have a strong voice in forestry and development interventions, intervening agencies need to consider the local heterogeneity of gender roles and differences in the establishment of decision-making structures (Pandolfelli et al. 2007, Coleman and Mwangi 2013).

The REDD+ social safety guard clearly advocates gender mainstreaming in REDD+ piloting and for full and effective participation of men and women in REDD+ activities (Gurung and Quesada-Aguilar 2009, Seymour and Angelsen 2009). Findings from our study reveal that REDD+ piloting is reproducing gender hierarchies in decision-making structures and inclusion in REDD+ activities. For example, the mechanism used to establish REDD+ village organizations excluded women from participating in decision making regarding REDD+ in the village because the membership was drawn from heads of households who are mainly men. Although the introduction meetings of REDD+ were aimed at informing the local people about the 
project, information about these meetings was mostly received by the men and shared among them. Women's limited access to information about REDD+ limits their ability to engage in REDD+ and articulate their interests. This conforms with the Larson et al. (2015) findings that women's limited knowledge about REDD+ was due to how information was disseminated and hence generally affected their participation in REDD+ implementation. In addition, household division of labor gives men more leisure time to be readily available to access information that comes into the village. Moreover, women have limited access to communication devices such as radio in the pilot sites because the men own and control households' communication devices. This reaffirms the issue of gendered ownership and access to household assets (Pandolfelli et al. 2007).

The fact that women's participation in meetings is strongly motivated by the per diems is often portrayed as captives to incentives rather than gender representation (Awung and Marchant 2016). In addition, women were also excluded from participating in the different REDD+ demonstration activities. Most of these activities were labelled as men's tasks, as perceived by the REDD+ pilot project organizers, because they required physical strength. The few women who participated as laborers in the water project were poorly paid compared to men while others were injured and not compensated. Given women's limited access to material resources (forestland, household assets) they had nominal participation, i.e., physical presence in meetings to earn per diems and working as laborers in project activities that provide financial relief to them, but their sense of inclusion in the project was low.

\section{Perceived barriers to women's participation}

The findings demonstrate that the key barrier to women's full and active participation in these interventions is rooted in the cultural and social norms of the study area. Social structures in both pilot sites are characterized by a patrilineal system of inheritance and access to material resources. These socio-cultural norms define a set of behavioral standards to which women need to adhere and are still very strong in Équateur province. The patriarchal sociocultural norms of the study area ascribe men as household heads giving them authority and decision-making power and control over their wives' participation in these interventions. Moreover, as household heads, men have the right to membership in the REDD+ village groups, and the right to access information and process it on behalf of their households. Most men in the project area are not ready to prioritize women's participation at the expense of household chores. Early REDD+ initiatives in Nepal also confirmed that men's power was influential in deciding women's participation in REDD+ processes in local-level forest institutions (Khadka et al. 2014). Men control socio-cultural norms to their advantage and may relax customary norms where they see that it is not to their direct benefit, as reflected by women's high representation in the agricultural training project of Mukumu-Bokola village.

The socio-cultural norms are embedded in virtually every sphere of activity in the pilot sites and prescribe behavior and social order. They define household division of labor, resources, public behavior, and social perceptions about women's contributions, needs, and abilities in the study areas. Many of these norms are regarded as what Bourdieu (1977) termed "doxa," an accepted part of social order not open to contestation, while some are immutable and some are contested by emerging emancipatory ideas and processes in the Bikoro pilot site (see Stiem and Krause 2016). Although men are engaged in activities that require physical strength, household division of labor allows them more leisure time to relax, socialize, and engage in nonproductive activities. Because men have more leisure time and dominate the activities in the public spheres, they are often ready and available to control the structures created by these interventions. On the other hand, women's heavy domestic responsibilities constrain their time commitment to participate in the decision-making activities. These findings indicates that women have a higher opportunity cost of their time than men, hence any intervention that considers women's time factor may have a better chance of succeeding than those that assume that women and men share the same motivations (Agarwal 2001, Pandolfelli et al. 2007, Coleman and Mwangi 2013).

The socio-cultural norms also ascribed different attributes, skills, and abilities to men and women in the study area. For example, many women reported that they do not feel confident and capable of talking in front of male community members in meetings. In addition, gender segregation in the public sphere limits their ability to engage in these meetings. Most of the women invited to meetings of the food security project in Buya 1 village sat on the floor while some brought their own chairs. Other scholars have documented how women who feel intimidated by gender segregation in the public sphere, may sit in the back of the room or on the floor and simply observe the decision-making processes (Nightingale 2002). Women who do speak up are often viewed negatively; their efforts to gain a voice in group projects are viewed as attempts to subvert gender norms. Moreover, women's knowledge of forests and contribution are undervalued in forest management decisions whereas men's knowledge is valued and considered as knowledge that counts in forest management decisions (Guarascio et al. 2013). Men's knowledge is embedded in the customary system of forest management; men control and make decisions. The undervaluation of women's knowledge affects their sense of inclusion in forest management decision making and excludes them from the benefits. In addition, in the REDD+ water project in Bikoro, the women hired were not paid because their contribution was undervalued. Similar findings have been reported by other scholars in Cameroon (Tiani et al. 2016). In community forestry programs in India and Nepal, Agarwal (2001) found that women were perceived as having little to add in terms of forest conservation and were frequently not invited to group meetings.

The social norms in the project area do not encourage education of female children. Instead, young girls are forced into early marriages (Ragasa et al. 2012). The low education of women limits their social acceptance and self-esteem and their ability to articulate their needs in village meetings. In both the pilot sites, women were perceived to have limited analytical thinking ability to be members of the executive committees because of their low level of education. The proactive women in the food security of Buya 1 village used their exposure, education, social network, and confidence to engage in the public arena. In the Congo Basin, many studies have shown how women's education has a positive effect in weakening the restrictive norms, combatting men's negative attitude, and enhancing women's participation (Stiem and Krause 2016, Guillaume 2017). 
Likewise, women who have access to and control over land and material resources increase their ability to influence decisions both within the households and in the community (Pandolfelli et al. 2007). In the project area, women do not control forestland based of customary laws, but maintain access via their husband or male relations (father, uncles, sons). This norm restricts them from participating and benefiting directly from any forestry interventions. Their limited access to and control over material resources of the households means they lack financial resources to become members of the OPDs. Because benefits from these OPDs are shared only among fee-paying members, they are excluded from these benefits. Ethnicity further restricts the Batwa and especially the Batwa women from participating. They are socially excluded and considered as laborers rather than full community members with agency. The Batwa are also secluded because of their lifestyle and experienced antipathies in these communities (see Stiem 2014, Samndong 2016).

\section{CONCLUSION}

This study shows that the gendered nature of knowledge, use and control over forests, are not always recognized in forestry and development interventions. Although women's knowledge and use of forests is important for food security and household cash income, they have less of a voice than men, and occupy nominal positions in forest decision-making and benefit-sharing arrangements compared with men. Women have limited access to land and other financial opportunities to increase their bargaining power to influence decisions and benefits from forestry and development interventions. Existing socio-cultural norms in the REDD+ pilot sites constrain women's abilities to be equally included in decision-making processes and benefit sharing from forestry and development interventions. These socio-cultural norms are embedded in virtually every sphere of activity in the pilots and prescribe behavior and social order. Women's limited access to information in the ongoing REDD+ pilot project further reduces their bargaining power. It would seem that the REDD+ pilot project views the households as a homogenous unit in the establishment of REDD+ village organizations. This further reproduces gender inequality in REDD+ decision-making processes. Moreover, women's participation in early REDD+ activities is constrained by the existing socio-cultural norms embedded in the participatory spaces.

Understanding the circular nature of women's inability to participate in the projects due to socio-cultural constraints is important to design localized and context-specific policies and practices. Women's subordination within forestry and development interventions, and the REDD+ in particular, needs special attention. Although women and men are able to influence change in institutions in their favor, women's lower level of power resources makes such outcomes more difficult to achieve. Thus, REDD+ actors should recognize the complex relationship between forests, gendered power dynamics, and REDD+ policies and practices, not only at the local level but also across the policy making spectrum. This complexity of both gender and institutional change means that favorable outcomes are not automatic. Making REDD+ gender transformative, however, depends on how REDD+ actors can be more effective in fostering gender equity by manipulating the existing socio-cultural norms.
[1] The Batwa is an ethnic group more commonly referred to as "Pygmy" in the region. They are also referred to as Peuples Autochtones (PA) in French, which means indigenous people.

[2] This region was a stronghold of former president Mobutu during the war of 1996-2002. After the war, the region became the stronghold of the main opposition party Mouvement de Liberation de Congo (MLC) of Jean Pierre Bemba under the Kabila administration limiting presidential supports and political priority.

${ }^{[3]}$ Food trees are tree species that provides food such as fruits, caterpillars, mushrooms, etc.

Responses to this article can be read online at: http://www.ecologyandsociety.org/issues/responses. $\mathrm{php} / 9753$

\section{Acknowledgments:}

We wish to thank the Norwegian Research Council for funding this research study. We are grateful to three anonymous reviewers for their critical comments to the early draft of this manuscript. We thank Millie Chapman of WHRC for producing the maps of the study area, WHRC field staff in Mbandaka for the technical support, and the field assistance for their support during the data collection process.

\section{LITERATURE CITED}

Agarwal, B. 1997. "Bargaining” and gender relations: within and beyond the household. Feminist Economics 3:1-51. http://dx.doi. org/10.1080/135457097338799

Agarwal, B. 2001. Participatory exclusions, community forestry, and gender: An analysis for South Asia and a conceptual framework. World Development 29:1623-1648. http://dx.doi. org/10.1016/S0305-750X(01)00066-3

Agarwal, B. 2010. Does women's proportional strength affect their participation? Governing local forests in South Asia. World Development 38:98-112. http://dx.doi.org/10.1016/j.worlddev.2009.04.001

Arora-Jonsson, S. 2013. Gender, development and environmental governance: theorizing connections. Routledge, New York, New York, USA.

Arora-Jonsson, S. 2014. Forty years of gender research and environmental policy: Where do we stand? Women's Studies International Forum 47 Part B:295-308. http://dx.doi.org/10.1016/ j.wsif.2014.02.009

Awung, N. S., and R. Marchant. 2016. Investigating the role of the local community as co-managers of the Mount Cameroon National Park Conservation Project. Environments 3:36. http:// dx.doi.org/10.3390/environments3040036

Awung, N. S., and R. Marchant. 2017. Quantifying local community voices in the decision-making process: insights from the Mount Cameroon National Park REDD+ project. Environmental Sociology 1-18. http://dx.doi.org/10.1080/232510$\underline{42.2017 .1363144}$ 
Bandiaky, S. 2008. Gender inequality in Malidino Biodiversity Community-based Reserve, Senegal: political parties and the 'Village Approach.' Conservation and Society 6:62.

Bourdieu, P. 1977. Outline of a theory of practice. Cambridge University Press, Cambridge, UK. http://dx.doi.org/10.1017/ $\underline{\text { CBO9780511812507 }}$

Brown, K., and S. Lapuyade. 2001. Changing gender relationships and forest: a case use study from Komassi, Cameroon. Pages 90-115 in C. J. P. Colfer and Y. Byron, editors. People managing forests: the links between human well-being and sustainability. Resources for the Future, Washington, D.C., USA.

Coleman, E. A., and E. Mwangi. 2013. Women's participation in forest management: a cross-country analysis. Global Environmental Change 23:193-205. http://dx.doi.org/10.1016/j.gloenvcha.2012.10.005

Colfer, C. J. P. 2013. The gender box: a framework for analysing gender roles in forest management. Center for International Forestry Research, Bogor, Indonesia.

Colfer, C. J. P., R. Achdiawan, H. Adnan, Erni, E. L. Yuliani, Balang, and LepMil. 2013. Gender and natural resource governance indicators: a need to assess and address 'sensitive and taboo' topics. Forests, Trees and Livelihoods 22:143-155. http://dx. doi.org/10.1080/14728028.2013.807143

Colfer, C. J. P., M. Elias, and R. Jamnadass. 2015. Women and men in tropical dry forests: a preliminary review. International Forestry Review 17:70-90. http://dx.doi.org/10.1505/146554815815834877

Cornwall, A. 2003. Whose voices? Whose choices? Reflections on gender and participatory development. World Development 31:1325-1342. http://dx.doi.org/10.1016/S0305-750X(03)00086$\underline{\mathrm{X}}$

Elmhirst, R. 2011. Introducing new feminist political ecologies. Geoforum 42:129-132. http://dx.doi.org/10.1016/j.geoforum.2011.01.006

Fraser, N. 1989. Unruly practices: power, discourse, and gender in contemporary social theory. University of Minnesota Press, Minneapolis, Minnesota, USA.

Government of Democratic Republic of Congo (GDRC). 2002. Forest Code. Law No. 1 1/2002 29 August, 2002. Kinshasa, DRC.

Guarascio, F., N. Gunewardena, C. Holding-Anyonge, S. Kaaria, L. Stloukal, B. Basnett, C. Colfer, E. Mwangi, B. Powell, and S. Shackleton. 2013. Forest, food security and gender: linkages, disparities and priorities for action. Background paper for the International Conference on Forests for Food Security and Nutrition. Food and Agriculture Organization, Rome, Italy.

Guillaume, E. 2017. A case study on inclusiveness in forest management decision-making mechanisms: a comparison of certified and non-certified forests in the Republic of the Congo. International Forestry Review 19:145-157. http://dx.doi. org/10.1505/146554817821255178

Gurung, J. D., and A. Quesada-Aguilar. 2009. Genderdifferentiated impacts of REDD to be addressed in REDD social standards. Global Gender and Climate Alliance series, Volume 13. Women Organizing for Change in Agriculture and Natural Resource Management.
Gurung, J., and A. B. Setyowati. 2012. Re-envisioning REDD+: gender, forest governance and REDD+ in Asia. Rights and Resources Initiative, Washington, D.C., USA.

Ingram, V., J. Schure, J. C. Tieguhong, O. Ndoye, A. Awono, and D. M. Iponga. 2014. Gender implications of forest product value chains in the Congo basin. Forests, Trees and Livelihoods 23:67-86. http://dx.doi.org/10.1080/14728028.2014.887610

Khadka, M., S. Karki, B. S. Karky, R. Kotru, and K. B. Darjee. 2014. Gender equality challenges to the REDD+ initiative in Nepal. Mountain Research and Development 34:197-207. http:// dx.doi.org/10.1659/MRD-JOURNAL-D-13-00081.1

Larson, A. M., T. Dokken, A. E. Duchelle, S. Atmadja, I. A. P. Resosudarmo, P. Cronkleton, M. Cromberg, W. Sunderlin, A. Awono, and G. Selaya. 2015. The role of women in early REDD+ implementation: lessons for future engagement. International Forestry Review 17:43-65. http://dx.doi.org/10.1505/146554815814725031

Mai, Y. H., E. Mwangi, and M. Wan. 2012. Gender analysis in forestry research. Looking back and thinking ahead. CIFOR Infobrief 51:1-6.

McDougall, C. 2001. Gender and diversity in assessing sustainable forest management and human well-being: reflections on assessment methods tests conducted in Bulungan, East Kalimantan, Indonesia. Pages 50-71 in C. Colfer and Y. Byron, editors. People managing forests: the links between human wellbeing and sustainability. Resources for the Future, Washington, D.C., USA.

Meinzen-Dick, R. S., L. R. Brown, H. S. Feldstein, and A. R. Quisumbing. 1997. Gender, property rights, and natural resources. World Development 25:1303-1315. http://dx.doi. org/10.1016/S0305-750X(97)00027-2

Mies, M., and V. Shiva. 1993. Ecofeminism. Zed Books, London, UK.

Mohanty, R. 2004. Institutional dynamics and participatory spaces: the making and unmaking of participation in local forest management in India. IDS Bulletin 35:26-32. http://dx.doi. org/10.1111/j.1759-5436.2004.tb00118.x

Mwangi, E., R. Meinzen-Dick, and Y. Sun. 2011. Gender and sustainable forest management in East Africa and Latin America. Ecology and Society 16(1):17. http://dx.doi.org/10.5751/ ES-03873-160117

Nhantumbo, I., and L. Chiwona-Karltun. 2012. His REDD+, her REDD+: how integrating gender can improve readiness. IIED Briefing. International Institute for Environment and Development, London, UK.

Nightingale, A. J. 2002. Participating or just sitting in? The dynamics of gender and caste in community forestry. Journal of Forest and Livelihood 2:1.

Oyono, P. R. 2004. Institutional deficit, representation, and decentralized forest mangement in Cameroon: elements of natural resource sociology for social theory and public policy. World Resources Institute and Center for International Forestry Research, Washington, D.C., USA. 
Pandolfelli, L., R. Meinzen-Dick, and S. Dohrn. 2007. Gender and collective action: a conceptual framework for analysis. International Food Policy Research Institute, Washington, D.C., USA.

Peach Brown, H. C. 2011. Gender, climate change and REDD+ in the Congo Basin forests of Central Africa. International Forestry Review 13:163-176. https://doi.org/10.1505/146554811797406651

Pretty, J. N. 1995. Participatory learning for sustainable agriculture. World Development 23:1247-1263. http://dx.doi. org/10.1016/0305-750X(95)00046-F

Quesada-Aguilar, A., and L. Aguilar. 2009. Gender and REDD+ road maps in Cameroon, Ghana and Uganda. ETFRN News 53 (Article 4.3):149-157.

Ragasa, C., A. Kinwa-Muzinga, and J. Ulimwengu. 2012. Gender assessment of the agricultural sector in the Democratic Republic of the Congo. International Food Policy Research Institute, Washington, D.C., USA.

Rocheleau, D. E. 1995. Gender and biodiversity: a feminist political ecology perspective. IDS Bulletin 26:9-16. http://dx.doi. org/10.1111/j.1759-5436.1995.mp26001002.X

Rocheleau, D., and D. Edmunds. 1997. Women, men and trees: gender, power and property in forest and agrarian landscapes. World Development 25:1351-1371. http://dx.doi.org/10.1016/ $\underline{\mathrm{S} 0305-750 \mathrm{X}(97) 00036-3}$

Rocheleau, D., E. Wangari, and B. Thomas-Slayter. 1996. Feminist political ecology: global issues and local experience. Routledge, London, UK.

Samndong, R. A. 2014. Socio-economic baseline study of REDD+ pilot project in Equateur province. Wood Hole Research Center, Mbandaka, Democratic Republic of Congo.

Samndong, R. A. 2016. Institutional choice and fragmented citizenship in forestry and development interventions in Bikoro Territory of the Democratic Republic of Congo. Forum for Development Studies 43:251-279. http://dx.doi.org/10.1080/0803$\underline{9410.2015 .1115426}$

Scott, J. C. 1985. Weapons of the weak: everyday forms of peasant resistance. Yale University Press, New Haven, Connecticut, USA.

Seymour, F., and A. Angelsen. 2009. Summary and conclusions: REDD wine in old wineskins? Realising REDD+: national strategy and policy options. Center for International Forestry Research, Bogor, Indonesia.

Stiem, L. 2014. 'Benefits beyond carbon' for whom? A gender analysis of communal forest governance and forest resource use in the Democratic Republic of Congo. Thesis. Lund University, Lund, Sweden.

Stiem, L., and T. Krause. 2016. Exploring the impact of social norms and perceptions on women's participation in customary forest and land governance in the Democratic Republic of Congoimplications for REDD+. International Forestry Review 18:110-122. http://dx.doi.org/10.1505/146554816818206113

Sunderland, T., R. Achdiawan, A. Angelsen, R. Babigumira, A. Ickowitz, F. Paumgarten, V. Reyes-García, and G. Shively. 2014. Challenging perceptions about men, women, and forest product use: a global comparative study. World Development 64:S56-S66. http://dx.doi.org/10.1016/j.worlddev.2014.03.003

Tiani, A. M., M. Y. Bele, R. Sufo-Kankeu, E. L. Chia, and A. S. Perez-Terán. 2016. Gender and forest decentralization in Cameroon: what challenges for adaptive capacity to climate change? Pages 106-125 in C. J. P. Colfer, B. S. Basnett, and M. Elias, editors. Gender and forests: climate change, tenure, value chains and emerging issues. Routledge, New York, New York, USA.

Tyagi, N., and S. Das. 2017. Gender mainstreaming in forest governance: analysing 25 years of research and policy in South Asia. International Forestry Review 19:234-244. http://dx.doi. org/10.1505/146554817821255132

Veuthey, S., and J.-F. Gerber. 2010. Logging conflicts in Southern Cameroon: a feminist ecological economics perspective. Ecological Economics 70:170-177. http://dx.doi.org/10.1016/j. ecolecon.2009.09.012

Weinberger, K. 2001. What role does bargaining power play in participation of women? A case study of rural Pakistan. Journal of Entrepreneurship 10:209-221. http://dx.doi.org/10.1177/09713$\underline{5570101000205}$

Yamba, P. K. 2009. Congo Basin-DRC: case study on the NgiriTumba-Maindombe Wetland Landscape. Institute for Environmental Security, The Hague, The Netherlands. 